\title{
Article \\ Quality and Safety of Pork Steak Marinated in Fermented Dairy Products and Sous-Vide Cooked
}

\author{
Agnieszka Latoch $(1$ and Justyna Libera * \\ Department of Animal Raw Materials Technology, University of Life Sciences in Lublin, 20-033 Lublin, Poland; \\ agnieszka.latoch@up.lublin.pl \\ * Correspondence: justyna.libera@up.lublin.pl
}

Received: 20 August 2019; Accepted: 8 October 2019; Published: 13 October 2019

check for updates

\begin{abstract}
Consumers expect the appropriate tenderness, juiciness, and taste, a well as sufficiently long shelf life from meat subjected to thermal processing. One of the methods used to achieve this effect is sous-vide (SV). However, the low temperatures used in this method may not be sufficient to ensure the safety of the meat product. In order to increase safety and reduce adverse sensory changes, we suggest marinating the meat in fermented dairy products (FDP). The aim of the study was to determine the impact of marinating meat in FDP (kefir, yogurt, buttermilk), marinating time (3-12 days), and SV temperature $\left(60\right.$ or $\left.80^{\circ} \mathrm{C}\right)$ on the quality and safety of pork steaks. Marinating the meat increases the level of loss during cooking, but at the same time, has no effect on the chemical composition and activity of water. The acidity of steaks decreases with the time of marinating. A few days of meat marinating in buttermilk or yogurt slows down the fat oxidation reactions and reduces the content of oxidizing substances in meat. Meat marinated in FDP and SV cooked contains acceptable microbial values. Marinating in FDP, especially in yogurt or buttermilk, improves the quality and safety of SV-cooked pork steaks.
\end{abstract}

Keywords: quality; natural marinating; meat product

\section{Introduction}

Consumers expect the appropriate tenderness, juiciness, and taste, as well as sufficiently long shelf life from meat subjected to thermal processing. One of the methods used to achieve this effect is sous-vide (SV). SV involves cooking the meat in vacuum-sealed thermostable bags at a low temperature (about $60{ }^{\circ} \mathrm{C}$ ) for a long time (above $6 \mathrm{~h}$ ) [1-4]. The method enables an effective transfer of heat from water (or steam) to a food, increases the food durability by reducing the growth of aerobic bacteria and eliminating the risk of reinfection during storage, inhibits unpleasant odors from the oxidation of both fats and proteins [3], prevents from the loss of volatile substances, and reduces the level of loss during cooking. However, low temperatures may not be sufficient to ensure the safety of meat products stored in the refrigerator for a longer time, and long storage at low temperatures may cause deterioration of SV meat dishes [2]. In order to extend the shelf life and reduce adverse sensory changes, we suggest marinating the meat in fermented dairy products (FDP). Meat marinating is a commonly used treatment that improves the culinary properties of meat [5-7]. Meat is usually marinated by soaking in an acidic solution to improve tenderness, taste, and smell [6], or to extend the shelf life of the product by limiting the growth of bacteria, especially pathogenic ones [8]. Many researchers attempt to use natural marinades such as lemon juice, lemon, pineapple marinades, potato tuber juice, soya sauce, wine sugar, organic acids, tamarind, lime, calamansi, and red wine [5,7,9-11]. However, in the available literature, there are no reports on the use of fermented dairy products (FDP) for meat marinating. In order to improve the quality and safety of pork steaks, we suggest marinating the meat before SV processing in fermented dairy products as part of food preservation using hurdle technology. 
We chose kefir (KE), yogurt (YO), and buttermilk (BM) because they are natural products that have beneficial effects on human health. Also, they are widely available, very popular, relatively cheap, and are the most consumed fermented milk products in Europe. $\mathrm{KE}, \mathrm{YO}$, and $\mathrm{BM}$ are products obtained by the fermentation of milk resulting from the action of suitable microorganisms [12]. The presence of live lactic acid bacteria cultures (LAB) can increase the durability of marinated meat $[5,13]$. LABs produce antimicrobial metabolites, including organic acids and bacteriocins [14]. Fermentation makes the $\mathrm{pH}$ of FDP slightly above 4 . The resulting metabolites prevent the development of pathogenic microorganisms from causing the meat to spoil, and also contribute to color stabilization and texture improvement [15]. In addition, the high content of calcium ions in FDP, with more than $100 \mathrm{mg}$ in $100 \mathrm{~g}$ product, can activate calpains, which increase the meat tenderness [7].

The aim of the study was to determine the effect of marinating meat in the $\mathrm{KE}, \mathrm{YO}$, or $\mathrm{BM}$ on chemical composition, water activity, redox potential, fat oxidation, and microbiological characteristics of pork steaks cooked for $6 \mathrm{~h}$ by means of $\mathrm{SV}$ at $60^{\circ} \mathrm{C}$ or $80^{\circ} \mathrm{C}$.

\section{Materials and Methods}

\subsection{Raw Material Preparation}

Twelve trimmed loins ( $m$. longissimus thoracis et lumborum) of Great White Poland pigs of 120-130 kg body weight were obtained from the slaughterhouse $24 \mathrm{~h}$ after the slaughter. The muscles were cut into $3 \mathrm{~cm}$ thick steaks weighing about $200 \mathrm{~g}$ each. Steaks were separately placed into plastic bags (cooking bags 80 GR vacuum cooking, ORVED S.p.A, Musile di Piave, Italy). Then, the steaks were immersed in liquid fermented dairy products (Dairy Cooperative MLEKOVITA, Wysokie Mazowieckie, Poland): Kefir (KE), buttermilk (BM), or yogurt (YO). After immersion in FDP, each meat was separately placed into the plastic bag and weighed. If necessary, the FDP was supplemented so that the FDP mass constituted $10 \%$ of the meat mass $(w / w)$. The bags were then vacuum-sealed (VAC-20 DT, Edesa, Barcelona, Spain) and stored for 3, 6, 9, or 12 days at $4{ }^{\circ} \mathrm{C}$ in the refrigerator. After a certain time, the vacuum-packed steaks were boiled in a water bath at $60^{\circ} \mathrm{C}$ or $80^{\circ} \mathrm{C}$ for $6 \mathrm{~h}$. After cooking, samples were cooled in ice water at $2{ }^{\circ} \mathrm{C}$ for $1 \mathrm{~h}$ and stored overnight at $4{ }^{\circ} \mathrm{C}$. Depending on the cooking temperature, the samples were marked as $\mathrm{KE} 6, \mathrm{BM} 6, \mathrm{YO} 6$, and $\mathrm{C} 6\left(\right.$ temp $\left.60^{\circ} \mathrm{C}\right)$ or $\mathrm{KE} 8$, BM8, YO8, and $\mathrm{C} 8$ (temp $80^{\circ} \mathrm{C}$ ). In total, 96 steaks were prepared: Eight samples (KE6, BM6, YO6, C6 KE8, BM8, $\mathrm{YO} 8, \mathrm{C} 8) \times$ four storage times $(3,6,9$ or 12 days $) \times$ three replicates. All analyses were performed in three replicates.

\subsection{Processing Loss}

The processing loss was calculated by measuring the differences in the weight of the raw steak before marinating and the marinated (for the appropriate time) steak after cooking sous-vide, chilling, removing from the bag, and drying on the filter paper. The moisture content in the cooking samples was determined by drying the samples $(5 \mathrm{~g})$ at $105^{\circ} \mathrm{C}$ under atmospheric pressure to constant weight according to ISO 1442:1997 [16].

\subsection{Chemical Composition Analysis of Cooked Samples}

\subsubsection{Protein Content}

The total nitrogen content was evaluated by the Kjeldahl method using a Kjeltec ${ }^{\mathrm{TM}} 8100$ (Foss Tecator, Höganäs, Sweden). The protein was calculated using the factor 6.25. An aliquot of $0.5 \mathrm{~g}$ dried sample was weighed into the distillation tube to the nearest $0,001 \mathrm{~g}$. Then, $12 \mathrm{~cm}^{3}$ of concentrated sulfuric acid (VI) $\left(1.84 \mathrm{~g} \mathrm{~cm}^{-3}\right)$ and two Kjeltabs $\mathrm{Cu}\left(\mathrm{K}_{2} \mathrm{SO}_{4}+\mathrm{CuSO}_{4} \cdot 5 \mathrm{H}_{2} \mathrm{O}\right)$ catalysts were added. The content was mineralized in the FOSS Kjeltec digest block at $420^{\circ} \mathrm{C}$ for $50 \mathrm{~min}$. After cooling, the mineralized samples were subjected to steam distillation in a Kjeltec device with a $4 \%$ boric acid solution in the receiver. The distillate was titrated with $0.19 \mathrm{M} \mathrm{HCl}$ in the presence of the 
Tashiro indicator to obtain a pink color. The protein content $(B)$ was calculated from the formula: $\mathrm{B}=(\mathrm{V} \times \mathrm{c} \times 14.007 \times 6.25 \times 100) / \mathrm{m}$, where $\mathrm{V}$-volume of hydrochloric acid used for titration $\left(\mathrm{cm}^{3}\right)$, c-molar concentration of hydrochloric acid used for titration $\left(\mathrm{cm}^{3}\right), 14.007$-amount of nitrogen that corresponds to $1 \mathrm{~cm}^{3}$ of 0.1 hydrochloric acid used for titration, 6.25-conversion factor for nitrogen content per protein for meat raw materials, and $\mathrm{m}$-sample weight $(\mathrm{mg})$. The obtained result was converted into protein content in the sample containing water.

\subsubsection{Total Fat Content}

The total fat was assayed by Soxhlet method according to ISO 1444:1996 [17]. A well-defined and weighed amount $(5-8 \mathrm{~g})$ of the minced and well-mixed samples was taken into a glass vessel. Samples were dried at $105^{\circ} \mathrm{C}$ in a drying oven to obtain constant weight. The samples were then cooled to room temperature in a desiccator and weighed. The dry matter was then calculated and dried samples were transferred into the Soxhlet equipment. The extraction, which involved applying petroleum ether, was performed for $6 \mathrm{~h}$ at $60^{\circ} \mathrm{C}$. After evaporation of the solvent, the flasks with fat were dried for $1 \mathrm{~h}$ at $100^{\circ} \mathrm{C}$ and cooled to a room temperature in desiccator and weighed. Intramuscular fat content (percentage) was calculated as follows: Fat $(\%)=($ fat weight after extraction $\times 100) /$ wet sample.

\subsection{Chemical Analysis}

\subsection{1. $\mathrm{pH}$ Value}

The $\mathrm{pH}$ was measured using a homogenate prepared with $10 \mathrm{~g}$ of sample and distilled water $(100 \mathrm{~mL})$ and digital $\mathrm{pH}$ meter CPC-501 (Elmetron, Zabrze, Poland) equipped with the $\mathrm{pH}$ electrode (ERH-111, Elmetron, Zabrze, Poland) according to ISO 2917:1999 [18].

\subsubsection{Redox Potential}

Redox potential (RP) was measured using a homogenate prepared of $10 \mathrm{~g}$ in $30 \mathrm{~mL}$ of deionized water using a digital RP-meter CPC-501 (Elmetron, Zabrze, Poland) set to the millivolt scale and equipped with redox electrode (ERPt-13, Elmetron, Zabrze, Poland) [19].

\subsubsection{Water Activity}

The water activity $\left(\mathrm{a}_{\mathrm{w}}\right)$ measurements were carried out at $20^{\circ} \mathrm{C}$ using a water activity analyzer LabMaster-aw (Novasina, Lachen, Switzerland).

\subsubsection{Lipid Oxidation}

The lipid oxidation was assessed using the thiobarbituric acid reactive substances' (TBARS) method [20]: $3 \mathrm{~g}$ of meat was ground and then homogenized with $12 \mathrm{~cm}^{3}$ of $4 \%$ cold perchloric acid $\left(4^{\circ} \mathrm{C}\right)$ and $200 \mu \mathrm{L}$ of an alcohol solution of butylhydroxytoluene-BHT $(0.01 \%)$ at a rotational speed of $11,000 \mathrm{rpm}$ for $1 \mathrm{~min}$. The contents were centrifuged at $4000 \mathrm{~g}$ for $10 \mathrm{~min}\left(4^{\circ} \mathrm{C}\right)$ and then filtered. After mixing, $650 \mu \mathrm{L}$ of the assay filtrate was withdrawn into the epitope and $650 \mu \mathrm{L}$ of a 0.02 molar aqueous solution of 2-thiobarbituric acid (TBA reagent) was added. Samples were heated in a boiling water bath for $0.5 \mathrm{~h}$. The absorbance at $532 \mathrm{~nm}$ was measured in a cooled sample using Nicole Evolution 300 spectrophotometer (Nicole Evolution 300, Thermo Fisher Scientific, Waltham, USA) against a control sample containing $650 \mu \mathrm{L}$ perchloric acid (4\%) and $650 \mu \mathrm{L}$ TBA reagent. The TBARS index value was expressed in mg malonaldehyde (MDA) per $\mathrm{kg}$ of meat, calculated from the formula: TBARS $=\mathrm{A} \times \mathrm{K} \times 10$, where $\mathrm{A}$ - the value of the abridged test sample and $\mathrm{K}$-conversion factor, which was calculated from the standard curve and applied settlements $\mathrm{K}=5.5$.

\subsection{Microbiological Analysis of Cooked Samples}

Samples were prepared according to standard ISO 6887-2:2017 [21]. Total viable counts of aerobic mesophilic bacteria were enumerated by pouring out onto plate count agar (Oxoid) and incubated at 
$30{ }^{\circ} \mathrm{C}$ for $72 \mathrm{~h}$ [22]. Total psychrotrophs were counted on plate count agar (PCA) (Oxoid) at $4{ }^{\circ} \mathrm{C}$ for seven days [23]. Total anaerobic psychrotrophs were counted on tryptone soya agar (TSA) (Oxoid) in anaerobic jars at $4{ }^{\circ} \mathrm{C}$ for seven days. Total Enterobacteriaceae were counted on violet red bile glucose agar (VRBG) plates (Oxoid) and incubated at $37^{\circ} \mathrm{C}$ for $24 \mathrm{~h}$ [24]. Pseudomonas counts were determined in Oxoid Pseudomonas selective agar with CFC supplement and incubated at $30^{\circ} \mathrm{C}$ for $72 \mathrm{~h}$ [25]. Lactic acid bacteria (LAB) were enumerated by plating on Man-Rogosa-Sharpe (MRS) agar (Oxoid) and incubated at $37^{\circ} \mathrm{C}$ for $24 \mathrm{~h}$ [26]. All counts were expressed as a log of colony forming units per gram of meat (log $\mathrm{CFU} \mathrm{g}{ }^{-1}$ of meat).

\subsection{Statistical Analysis}

The fix effect of processing (kind of FDP, time of marinating, and temperature of SV) and random effect of replications were included in the model. Analysis of variance (ANOVA) was performed on all variables using the general linear model process of the SAS 9.1.3. (SAS Institute Inc., Cary, NC, USA) statistical software. The differences in mean values were compared by Tukey's multiple comparison method, and mean values and standard deviation of the means were reported $(p<0.05)$.

\section{Results and Discussion}

\subsection{Processing Loss}

The SV-cooked steaks at $80^{\circ} \mathrm{C}$ showed significantly higher weight loss $(p<0.05)$ than those cooked at $60^{\circ} \mathrm{C}$, regardless of other factors tested (Table 1). Marinating time also influenced this parameter. The longer the time of sample marinating, the bigger the level of loss during cooking $(p<0.05)$. Particularly, these differences could be seen in samples cooked at $60^{\circ} \mathrm{C}$. To a lesser extent, the time of marinating had an effect on cooking losses of samples cooked at $80^{\circ} \mathrm{C}$. Although in this case, meat marinating for six days contributed to the reduction in the weight loss. Results obtained in this study are comparable to those found by other authors [1]. Generally, it was found that weight losses of steaks marinated in FDP, especially for three, six, or nine days, and SV-cooked were significantly higher $(p<0.05)$ as compared to the control steaks. The 12-day steak marinating did not significantly affect the tested feature.

Table 1. Effect of marinating time and type of marinade on weight losses of cooked sous-vide (SV) pork steaks (\%) (means \pm standard deviation).

\begin{tabular}{ccccc}
\hline \multirow{2}{*}{ Sample } & \multicolumn{4}{c}{ Marinating Time (Days) } \\
\cline { 2 - 5 } & $\mathbf{3}$ & $\mathbf{6}$ & $\mathbf{9}$ & $\mathbf{1 2}$ \\
\hline C6 & $22.39 \pm 4.25^{\mathrm{a}, \mathrm{A}}$ & $25.68 \pm 0.85^{\mathrm{a}, \mathrm{A}}$ & $20.99 \pm 6.51^{\mathrm{a}, \mathrm{A}}$ & $29.29 \pm 6.11^{\mathrm{a}, \mathrm{A}}$ \\
KE6 & $30.15 \pm 2.15^{\mathrm{b}, \mathrm{A}, \mathrm{B}}$ & $24.06 \pm 5.02^{\mathrm{a}, \mathrm{b}, \mathrm{A}}$ & $27.31 \pm 1.97^{\mathrm{a}, \mathrm{A}}$ & $35.20 \pm 3.43^{\mathrm{a}, \mathrm{B}}$ \\
BM6 & $32.12 \pm 4.13^{\mathrm{b}, \mathrm{c}, \mathrm{A}}$ & $29.38 \pm 3.19^{\mathrm{a}, \mathrm{b}, \mathrm{c}, \mathrm{A}}$ & $35.06 \pm 3.11^{\mathrm{b}, \mathrm{c}, \mathrm{A}}$ & $37.40 \pm 5.55^{\mathrm{a}, \mathrm{A}}$ \\
YO6 & $28.93 \pm 4.95^{\mathrm{a}, \mathrm{b}, \mathrm{A}}$ & $32.38 \pm 3.22^{\mathrm{b}, \mathrm{c}, \mathrm{A}}$ & $32.75 \pm 2.89^{\mathrm{b}, \mathrm{A}}$ & $39.62 \pm 5.75^{\mathrm{a}, \mathrm{A}}$ \\
\hline C8 & $35.75 \pm 0.98^{\mathrm{c}, \mathrm{A}}$ & $30.32 \pm 0.03^{\mathrm{c}, \mathrm{B}}$ & $38.85 \pm 1.98^{\mathrm{c}, \mathrm{C}}$ & $43.35 \pm 6.73^{\mathrm{a}, \mathrm{C}}$ \\
KE8 & $40.03 \pm 1.52^{\mathrm{d}, \mathrm{A}, \mathrm{B}}$ & $36.17^{\mathrm{a}} \pm 4.68^{\mathrm{d}, \mathrm{A}}$ & $40.84 \pm 2.82^{\mathrm{c}, \mathrm{d}, \mathrm{A}, \mathrm{B}}$ & $45.97 \pm 4.95^{\mathrm{a}, \mathrm{B}}$ \\
BM8 & $40.39 \pm 2.02^{\mathrm{d}, \mathrm{A}}$ & $34.56 \pm 3.76^{\mathrm{d}, \mathrm{A}}$ & $44.26 \pm 1.03^{\mathrm{d}, \mathrm{B}}$ & $45.70 \pm 3.15^{\mathrm{a}, \mathrm{A}, \mathrm{B}}$ \\
YO8 & $40.66 \pm 0.25^{\mathrm{d}, \mathrm{A}}$ & $34.56 \pm 3.47^{\mathrm{d}, \mathrm{B}}$ & $42.34 \pm 0.38^{\mathrm{e}, \mathrm{C}}$ & $42.79 \pm 3.35^{\mathrm{a}, \mathrm{C}}$ \\
\hline
\end{tabular}

Means within a row with different capital letters and means within a column with different small letters are differ significantly $(p<0.05)$. $\mathrm{C} 6=$ control, $60{ }^{\circ} \mathrm{C}$; KE6 = kefir, $60^{\circ} \mathrm{C} ; \mathrm{BM}=$ buttermilk, $60{ }^{\circ} \mathrm{C}$; YO6 = yogurt $60^{\circ} \mathrm{C}$; $\mathrm{C} 6=$ control, $80^{\circ} \mathrm{C} ; \mathrm{KE} 6=$ kefir, $80^{\circ} \mathrm{C} ; \mathrm{BM}=$ buttermilk, $80^{\circ} \mathrm{C}$; YO6 $=$ yogurt $80^{\circ} \mathrm{C}$.

Loss of weight during meat cooking results mainly from changes in proteins. At $40{ }^{\circ} \mathrm{C}$, myofibrillar proteins begin to shrink. This process becomes more intense as the temperature increases. The shrinkage of myofibrillar proteins results in tightening of the muscle fiber structures and, as a consequence, reduction of its volume and reduction in the ability to maintain water. Likewise, the interstitial spaces tighten, and as a result, some of the capillary water is lost during cooking. Further heating between 56 
and $62{ }^{\circ} \mathrm{C}$ also causes changes in the perimysium of the connective tissue $[27,28]$. Contraction of the connective tissue causes the compression of muscle fiber bundles, which deepens the process of water separation. According to Sánchez del Pulgar et al. [4], the SV cooking method or cooking directly in water does not affect the juiciness of meat. The loss of water results from the temperature used. Vacuum cooking itself does not cause more juice retention in the meat. It may, however, under certain conditions, cause slightly larger losses of water resulting from the physical increase of pressure exerted on the meat during vacuum packaging and from partial exudation of surface water caused by the vacuum. Nevertheless, water is not the only component lost during cooking. Along with water, other water-soluble components are lost. Using the SV method, losses of these components are reduced. If the cooking temperature exceeds the collagen solubility temperature, these components are bound in the gelatin structure after cooling [4].

\subsection{Chemical Composition}

The chemical composition of SV-cooked steaks marinated for three days is given in Figure 1. The moisture content in steaks cooked at $60{ }^{\circ} \mathrm{C}$ was higher than those cooked at $80{ }^{\circ} \mathrm{C}(p<0.05)$. Similar relations were found by Sánchez del Pulgar et al. [4], who cooked the pork cheeks using the SV method $\left(60^{\circ} \mathrm{C}\right.$ or $80^{\circ} \mathrm{C} ; 6$ or $\left.12 \mathrm{~h}\right)$. No effect $(p<0.05)$ of marinating in $\mathrm{KE}, \mathrm{YO}$, or $\mathrm{BM}$ on the moisture level in steaks cooked at $60^{\circ} \mathrm{C}$, was recorded. Marinating in $\mathrm{YO}$ or BM reduced the moisture level in steaks cooked at $80{ }^{\circ} \mathrm{C}$ compared to the control and samples marinated in KE. The method of processing the steaks did not affect $(p<0.05)$ the protein and fat content. Acidic marinating is a common method of improving the technical and functional properties of meat [6]. Changing the $\mathrm{pH}$ causes changes in the water retention capacity $[29,30]$. This property is correlated with swelling and/or increased extractive ability of myofibrillar proteins, which results from the increase in ionic strength and decrease in $\mathrm{pH}[31,32]$. However, it has been found that acidic meat marinating causes various effects in the microstructure, e.g., swelling and contraction of muscles due to changes in myofibrils occurs above $\mathrm{pH}$ 4.3. Below $\mathrm{pH} 4.3$, there is also a swelling of collagen, mainly perimysium. During cooking, swollen muscle fibers maintain a high degree of water binding and are also more resistant to thermal shrinkage due to lower thermal sensitivity of collagen.

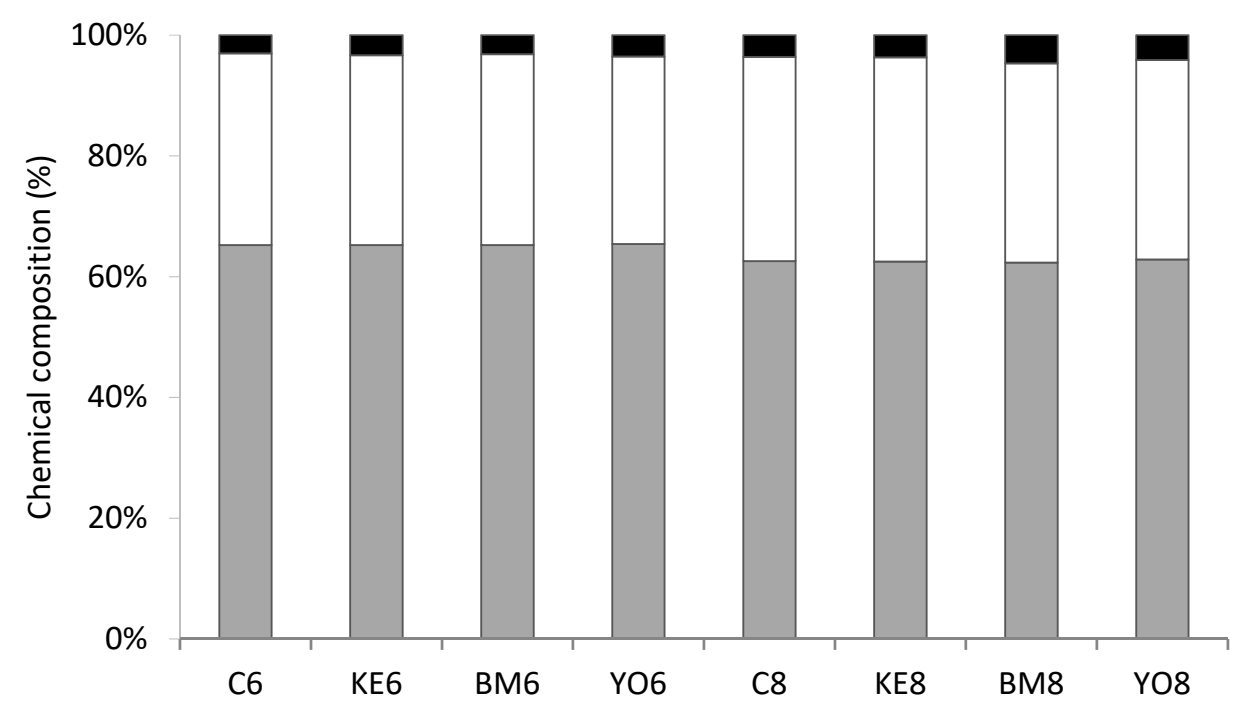

Figure 1. Chemical composition (\%): - Fat, $\square$ protein, $\square$ moisture of pork steaks marinated for three days in kefir, yogurt or buttermilk and cooked using the SV method. $\mathrm{C} 6=$ control, $60{ }^{\circ} \mathrm{C}$; $\mathrm{KE6}=$ kefir, $60^{\circ} \mathrm{C} ; \mathrm{BM}=$ buttermilk, $60^{\circ} \mathrm{C}$; YO6 = yogurt $60^{\circ} \mathrm{C} ; \mathrm{C} 6=$ control, $80^{\circ} \mathrm{C}$; KE6 = kefir, $80{ }^{\circ} \mathrm{C}$; $\mathrm{BM}=$ buttermilk, $80^{\circ} \mathrm{C}$; $\mathrm{YO} 6=$ yogurt $80^{\circ} \mathrm{C}$. 


\subsection{Chemical Analysis}

\subsection{1. $\mathrm{pH}$ Value}

As expected, the $\mathrm{pH}$ of steaks marinated for three days in fermented dairy products and cooked using the SV method was lower $(p<0.05)$ than that of the control steaks (Table 2). The action of suitable microorganisms in fermented dairy products caused a decrease in $\mathrm{pH}$ [12]. The $\mathrm{pH}$ of KE was around 4.2 due to the presence of organic acids, ethanol, $\mathrm{CO}_{2}$, and other volatile compounds [33]. The $\mathrm{pH}$ value of $\mathrm{YO}$ was 4.4 due to the fact that $\mathrm{LABs}$ were able to convert lactose to lactic acid. BM is a byproduct of whipping the sweet cream into butter, produced with the participation of Lactococcus and Leuconostoc, and has a $\mathrm{pH}$ of about 4.5. The $\mathrm{pH}$ value of steaks decreased $(p<0.05)$ with marinating duration regardless of the marinade type. This was mainly due to the fact that during marinating for 12 days, lactic bacteria are still alive, and growing produces compounds, mainly acids, which increase the acidity of environment. Marinating in YO significantly $(p<0.05)$ reduced the $\mathrm{pH}$ of SV cooked steaks at $60^{\circ} \mathrm{C}$ compared to other samples.

Table 2. Effect of marinating time and type of marinade on the $\mathrm{pH}$ of SV-cooked steaks (means \pm standard deviation).

\begin{tabular}{|c|c|c|c|c|}
\hline \multirow{2}{*}{ Sample } & \multicolumn{4}{|c|}{ Marinating Time (Days) } \\
\hline & 3 & 6 & 9 & 12 \\
\hline C6 & $5.83 \pm 0.01^{\mathrm{a}, \mathrm{A}}$ & $5.60 \pm 0.04^{a, B}$ & $5.61 \pm 0.02 \mathrm{a}, \mathrm{B}$ & $5.58 \pm 0.04^{\mathrm{a}, \mathrm{B}}$ \\
\hline KE6 & $5.74 \pm 0.05^{\mathrm{b}, \mathrm{A}}$ & $5.59 \pm 0.05^{a, B}$ & $5.66 \pm 0.04^{\mathrm{a}, \mathrm{B}}$ & $5.50 \pm 0.02^{a, C}$ \\
\hline BM6 & $5.74 \pm 0.06^{\mathrm{b}, \mathrm{A}}$ & $5.60 \pm 0.01^{\mathrm{a}, \mathrm{B}}$ & $5.66 \pm 0.05^{\mathrm{a}, \mathrm{B}}$ & $5.54 \pm 0.03^{a, C}$ \\
\hline YO6 & $5.72 \pm 0.02^{\mathrm{b}, \mathrm{A}}$ & $5.51 \pm 0.03 \mathrm{~b}, \mathrm{~B}$ & $5.53 \pm 0.02 \mathrm{~b}, \mathrm{~B}$ & $5.37 \pm 0.03^{b, c}$ \\
\hline C8 & $5.84 \pm 0.03^{\mathrm{a}, \mathrm{A}}$ & $5.64 \pm 0.02^{a, B}$ & $5.57 \pm 0.01^{a, C}$ & $5.58 \pm 0.06^{a, C}$ \\
\hline KE8 & $5.79 \pm 0.01 \mathrm{~b}, \mathrm{~A}$ & $5.65 \pm 0.04^{\mathrm{a}, \mathrm{B}}$ & $5.65 \pm 0.05^{\mathrm{a}, \mathrm{B}}$ & $5.54 \pm 0.03^{a, C}$ \\
\hline BM8 & $5.78 \pm 0.04 \mathrm{~b}, \mathrm{~A}$ & $5.63 \pm 0.01^{\mathrm{a}, \mathrm{B}}$ & $5.64 \pm 0.05^{\mathrm{a}, \mathrm{B}}$ & $5.53 \pm 0.12^{a, C}$ \\
\hline YO8 & $5.76 \pm 0.06^{\mathrm{b}, \mathrm{A}}$ & $5.60 \pm 0.03^{a, B}$ & $5.52 \pm 0.03 b, c$ & $5.39 \pm 0.06^{b, D}$ \\
\hline
\end{tabular}

Means within a row with different capital letters and means within a column with different small letters are differ significantly $(p<0.05) . \mathrm{C} 6=$ control, $60^{\circ} \mathrm{C} ; \mathrm{KE} 6=$ kefir, $60^{\circ} \mathrm{C} ; \mathrm{BM}=$ buttermilk, $60^{\circ} \mathrm{C}$; YO6 = yogurt $60^{\circ} \mathrm{C}$; $\mathrm{C} 6=$ control, $80^{\circ} \mathrm{C} ; \mathrm{KE} 6=$ kefir, $80^{\circ} \mathrm{C} ; \mathrm{BM}=$ buttermilk, $80{ }^{\circ} \mathrm{C}$; YO6 $=$ yogurt $80^{\circ} \mathrm{C}$.

\subsubsection{Water Activity}

The water activity $\left(\mathrm{a}_{\mathrm{w}}\right)$ in food products is determined by degree of water connection with other food ingredients and determines the speed of many chemical and enzymatic reactions occurring in food, e.g., hem dyes are faster oxidized when $a_{w}$ is higher. The $a_{w}$ value in raw meat is 0.99 , whereas in meat products after heat treatment, it amounts from 0.93 to 0.97 [34]. In these studies, for steaks marinated in $\mathrm{KE}, \mathrm{BM}$, or $\mathrm{YO}$ and cooked using the SV method at $60^{\circ} \mathrm{C}$ or $80^{\circ} \mathrm{C}$, it was about 0.94 (Table 3). Type of marinade, regardless of the marinating time, did not significantly affect the value of water activity in particular research periods. However, a significant effect $(p<0.05)$ of the marinating duration on $\mathrm{a}_{\mathrm{w}}$ was recorded. The smaller the $a_{w}$ value, the longer the marinating time was. Since $a_{w}$ depends on the quantity and quality of food ingredients, among other factors, a significant reduction in its level after 12 days of marinating may result from the decomposition of meat chemical components, mainly proteins, into smaller molecules due to enzymes and bacteria contained in meat and in fermented dairy products added to marinating. In addition, lactic acid, which naturally occurs during meat maturation and is naturally found in $\mathrm{KE}, \mathrm{BM}$, and $\mathrm{YO}$, may have a significant impact on these changes. Lowering the $\mathrm{pH}$ of meat to the optimum level for cathepsin activity in the range of 3.5-5.0 may significantly increase the proteolytic attack of these enzymes [7,35]. In addition, dairy products are a source of calcium that act as a post mortem activator of other enzymes of calpains [36]. 
Table 3. Effect of marinating time and type of marinade on the water activity of SV-cooked steaks (means \pm standard deviation).

\begin{tabular}{|c|c|c|c|c|}
\hline \multirow{2}{*}{ Sample } & \multicolumn{4}{|c|}{ Marinating Time (Days) } \\
\hline & 3 & 6 & 9 & 12 \\
\hline $\mathrm{C} 6$ & $0.946 \pm 0.002^{\mathrm{a}, \mathrm{A}}$ & $0.948 \pm 0.002^{\mathrm{a}, \mathrm{A}}$ & $0.947 \pm 0.001 \mathrm{a}, \mathrm{A}$ & $0.943 \pm 0.001^{\mathrm{a}, \mathrm{B}}$ \\
\hline KE6 & $0.948 \pm 0.003^{\mathrm{a}, \mathrm{A}}$ & $0.949 \pm 0.001 \mathrm{a}, \mathrm{A}$ & $0.947 \pm 0.001 \mathrm{a}, \mathrm{A}$ & $0.943 \pm 0.001 \mathrm{a}, \mathrm{B}$ \\
\hline BM6 & $0.947 \pm 0.003^{\mathrm{a}, \mathrm{A}}$ & $0.949 \pm 0.002^{\mathrm{a}, \mathrm{A}}$ & $0.946 \pm 0.002 \mathrm{a}, \mathrm{A}$ & $0.943 \pm 0.001 \mathrm{a}, \mathrm{B}$ \\
\hline YO6 & $0.947 \pm 0.003^{\mathrm{a}, \mathrm{A}}$ & $0.948 \pm 0.003^{\mathrm{a}, \mathrm{A}}$ & $0.947 \pm 0.002 \mathrm{a}, \mathrm{A}$ & $0.943 \pm 0.001 \mathrm{a}, \mathrm{B}$ \\
\hline $\mathrm{C} 8$ & $0.947 \pm 0.003^{\mathrm{a}, \mathrm{A}}$ & $0.946 \pm 0.003^{\mathrm{a}, \mathrm{A}}$ & $0.946 \pm 0.002^{\mathrm{a}, \mathrm{A}}$ & $0.942 \pm 0.001^{\mathrm{a}, \mathrm{B}}$ \\
\hline KE8 & $0.947 \pm 0.002^{\mathrm{a}, \mathrm{A}}$ & $0.946 \pm 0.003^{\mathrm{a}, \mathrm{A}, \mathrm{B}}$ & $0.945 \pm 0.0011^{\mathrm{a}, \mathrm{B}}$ & $0.943 \pm 0.001^{\mathrm{a}, \mathrm{B}}$ \\
\hline BM8 & $0.946 \pm 0.001^{\mathrm{a}, \mathrm{A}}$ & $0.947 \pm 0.003^{\mathrm{a}, \mathrm{A}}$ & $0.945 \pm 0.001 \mathrm{a}, \mathrm{A}$ & $0.942 \pm 0.001^{\mathrm{a}, \mathrm{B}}$ \\
\hline YO8 & $0.946 \pm 0.003^{\mathrm{a}, \mathrm{A}}$ & $0.948 \pm 0.001^{\mathrm{a}, \mathrm{A}}$ & $0.945 \pm 0.002^{\mathrm{a}, \mathrm{A}}$ & $0.943 \pm 0.002^{\mathrm{a}, \mathrm{B}}$ \\
\hline
\end{tabular}

Means within a row with different capital letters and means within a column with different small letters are differ significantly $(p<0.05) . \mathrm{C} 6=$ control, $60^{\circ} \mathrm{C} ; \mathrm{KE} 6=$ kefir, $60^{\circ} \mathrm{C} ; \mathrm{BM}=$ buttermilk, $60{ }^{\circ} \mathrm{C}$; YO6 = yogurt $60{ }^{\circ} \mathrm{C}$; $\mathrm{C} 6=$ control, $80^{\circ} \mathrm{C} ; \mathrm{KE} 6=\mathrm{kefir}, 80^{\circ} \mathrm{C} ; \mathrm{BM}=$ buttermilk, $80^{\circ} \mathrm{C} ; \mathrm{YO} 6=$ yogurt $80^{\circ} \mathrm{C}$.

\subsubsection{Lipid Oxidation}

The TBARS results obtained in the first test period with samples after three days of marinating and SV cooking at $60{ }^{\circ} \mathrm{C}$ are significantly higher $(p<0.05)$ than in the finished samples at $80{ }^{\circ} \mathrm{C}$ (Table 4). Nonetheless, TBARS values do not exceed the threshold value of $3 \mathrm{mg} \mathrm{MDA} \mathrm{kg} \mathrm{of}^{-1}$ product. Sánchez del Pulgar et al. [4] obtained significantly higher TBARS values, from 2.4 to $4.0 \mathrm{mg}$ MDA per kilogram of SV-cooked pork cheeks. They found that this was the result of a long-term (6 or $12 \mathrm{~h}$ ) thermal treatment, which caused an increase in lipid oxidation. However, the authors did not use any marinade. Our research revealed the influence of marinating time on the reduction of TBARS value.

Table 4. Effect of marinating time and type of marinade on the thiobarbituric acid reactive substances' (TBARS) value (mg MDA $100 \mathrm{~g}^{-1}$ of product) of SV-cooked steaks (means \pm standard deviation).

\begin{tabular}{ccccc}
\hline \multirow{2}{*}{ Sample } & \multicolumn{4}{c}{ Marinating Time (Days) } \\
\cline { 2 - 5 } & $\mathbf{3}$ & $\mathbf{6}$ & $\mathbf{9}$ & $\mathbf{1 2}$ \\
\hline C6 & $2.33 \pm 0.00^{\mathrm{a}, \mathrm{A}}$ & $1.04 \pm 0.19^{\mathrm{a}, \mathrm{B}}$ & $0.76 \pm 0.52^{\mathrm{a}, \mathrm{B}}$ & $0.35 \pm 0.07^{\mathrm{a}, \mathrm{C}}$ \\
KE6 & $2.03 \pm 0.14^{\mathrm{b}, \mathrm{A}}$ & $0.90 \pm 0.21^{\mathrm{b}, \mathrm{B}}$ & $1.08 \pm 0.51^{\mathrm{b}, \mathrm{B}}$ & $0.55 \pm 0.17^{\mathrm{b}, \mathrm{C}}$ \\
$\mathrm{BM6}$ & $2.13 \pm 0.26^{\mathrm{b}, \mathrm{A}}$ & $0.73 \pm 0.20^{\mathrm{c}, \mathrm{B}}$ & $0.86 \pm 0.36^{\mathrm{a}, \mathrm{b}, \mathrm{B}}$ & $0.32 \pm 0.10^{\mathrm{a}, \mathrm{C}}$ \\
YO6 & $1.98 \pm 0.12^{\mathrm{b}, \mathrm{A}}$ & $0.54 \pm 0.06^{\mathrm{d}, \mathrm{B}}$ & $0.71 \pm 0.17^{\mathrm{a}, \mathrm{B}}$ & $0.33 \pm 0.03^{\mathrm{a}, \mathrm{C}}$ \\
\hline C8 & $1.51 \pm 0.12^{\mathrm{d}, \mathrm{A}}$ & $0.25 \pm 0.02^{\mathrm{e}, \mathrm{B}}$ & $0.30 \pm 0.04^{\mathrm{c}, \mathrm{B}}$ & $0.23 \pm 0.03^{\mathrm{c}, \mathrm{B}}$ \\
KE8 & $0.74 \pm 0.03^{\mathrm{e}, \mathrm{B}}$ & $0.31 \pm 0.09^{\mathrm{f}, \mathrm{B}}$ & $0.34 \pm 0.08^{\mathrm{c}, \mathrm{B}}$ & $0.22 \pm 0.02^{\mathrm{c}, \mathrm{B}}$ \\
BM8 & $0.59 \pm 0.02^{\mathrm{f}, \mathrm{B}}$ & $0.32 \pm 0.04^{\mathrm{f}, \mathrm{B}}$ & $0.36 \pm 0.04^{\mathrm{c}, \mathrm{B}}$ & $0.25 \pm 0.04^{\mathrm{c}, \mathrm{B}}$ \\
YO8 & $0.66^{\mathrm{c}} \pm 0.03^{\mathrm{g}, \mathrm{B}}$ & $0.23 \pm 0.05^{\mathrm{e}, \mathrm{B}}$ & $0.32^{\mathrm{C}} \pm 0.08^{\mathrm{c}, \mathrm{B}}$ & $0.24 \pm 0.05^{\mathrm{c}, \mathrm{B}}$ \\
\hline
\end{tabular}

Means within a row with different capital letters and means within a column with different small letters are differ significantly $(p<0.05)$. C6 = control, $60^{\circ} \mathrm{C}$; $\mathrm{KE} 6=$ kefir, $60{ }^{\circ} \mathrm{C} ; \mathrm{BM}=$ buttermilk, $60{ }^{\circ} \mathrm{C}$; YO6 = yogurt $60{ }^{\circ} \mathrm{C}$; $\mathrm{C} 6=$ control, $80^{\circ} \mathrm{C} ; \mathrm{KE} 6=$ kefir, $80^{\circ} \mathrm{C} ; \mathrm{BM}=$ buttermilk, $80^{\circ} \mathrm{C}$; YO6 = yogurt $80^{\circ} \mathrm{C}$.

It was found that a few days of meat marinating in $\mathrm{BM}$ or $\mathrm{YO}$ caused significant slowdown in the fat oxidation reaction rate. This aspect requires further research. One of the reasons may be the fact that some Lactobacilli have antioxidant activity and are able to reduce the risk of reactive oxygen species. Lactic acid bacteria can break down the peroxide anion and hydrogen peroxide. Several peptides with antioxidant activity have also been identified in fermented dairy products. Milk protein hydrolysates may increase the oxidative stability of a product, including meat [37]. Studies conducted by Diaz and Decker [38] have shown that adding the milk protein hydrolysates to minced and cooked beef inhibited the formation of malonic aldehyde. The authors believed that cooking increased the catalytic activity of iron contained in meat, while the addition of milk protein hydrolysates, which have strong chelating activity, can effectively reduce the oxidation process. Casein calcium peptides present in 
fermented dairy products also have strong antioxidant activity against lipid oxidation. These peptides can be as effective as other antioxidants, preventing the formation of unpleasant aftertaste in meat products and extending the shelf life.

\subsubsection{Redox Potential}

Redox potential (RP) expresses the progress degree of biological and chemical reactions that cause the oxidative reactions. The RP value depends on the number of oxidants and reducers contained in the meat. The more oxidants, the higher the RP value. Factors that affect the RP include $\mathrm{pH}$, water activity, oxygen, biochemical processes, and concentration of reagents. Table 5 shows results of the impact of marinating duration and type of marinade on the RP value of SV-cooked pork steaks. The RP value of steaks cooked at $80^{\circ} \mathrm{C}$ was lower $(p<0.05)$ than those cooked at lower temperatures. The short-term marinating of steaks (three days) did not affect the RP. The RP value decreased with the marinating time, especially in steaks marinated in $\mathrm{BM}$ and $\mathrm{YO}$, regardless of the SV cooking temperature. One of the reasons for lowering the RP value was the lower $\mathrm{pH}$ of steaks as a result of marination in KE, $\mathrm{BM}$, or YO. At the same time, it was suggested that RP and TBARS of steaks marinated in KE for six days were higher $(p<0.05)$ than those of steaks marinated in YO and BM. Perhaps, this was due to the presence of ethanol in KE.

Table 5. Effect of marinating time and type of marinade on the redox potential value $(\mathrm{mV})$ of SV-cooked steaks (means \pm standard deviation).

\begin{tabular}{|c|c|c|c|c|}
\hline \multirow{2}{*}{ Sample } & \multicolumn{4}{|c|}{ Marinating Time (Days) } \\
\hline & 3 & 6 & 9 & 12 \\
\hline C6 & $288.5 \pm 2.2^{\mathrm{a}, \mathrm{A}}$ & $305.5 \pm 1.9^{a, B}$ & $315.0 \pm 0.8^{a, C}$ & $270.5 \pm 4.0^{\mathrm{a}, \mathrm{D}}$ \\
\hline KE6 & $290.4 \pm 2.5^{\mathrm{a}, \mathrm{A}}$ & $306.8 \pm 3.9^{\mathrm{a}, \mathrm{B}}$ & $289.0 \pm 4.7^{\mathrm{b}, \mathrm{A}}$ & $273.9 \pm 1.1^{\mathrm{b}, \mathrm{D}}$ \\
\hline BM6 & $293.9 \pm 1.6^{\mathrm{a}, \mathrm{A}}$ & $280.1 \pm 3.2^{b, B}$ & $276.0 \pm 1.0^{\mathrm{b}, \mathrm{C}}$ & $270.8 \pm 1.3^{\mathrm{a}, \mathrm{D}}$ \\
\hline YO6 & $274.7 \pm 1.6^{\mathrm{b}, \mathrm{A}}$ & $280.2 \pm 1.9^{b, B}$ & $265.5 \pm 2.4^{c, B}$ & $258.3 \pm 0.9^{\mathrm{c}, \mathrm{D}}$ \\
\hline $\mathrm{C} 8$ & $266.8 \pm 4.0^{\mathrm{c}, \mathrm{A}}$ & $276.8 \pm 0.9^{\mathrm{d}, \mathrm{B}}$ & $280.5 \pm 2.0^{\mathrm{a}, \mathrm{C}}$ & $283.2 \pm 1.5^{b, C}$ \\
\hline KE8 & $271.6 \pm 3.1^{\mathrm{c}, \mathrm{A}}$ & $285.8 \pm 1.3^{\mathrm{c}, \mathrm{B}}$ & $271.1 \pm 1.3^{\mathrm{c}, \mathrm{A}}$ & $263.8 \pm 1.1^{b, C}$ \\
\hline BM8 & $267.5 \pm 2.1^{\mathrm{c}, \mathrm{A}}$ & $263.0 \pm 3.7^{\mathrm{b}, \mathrm{A}}$ & $255.5 \pm 1.3^{\mathrm{d}, \mathrm{B}}$ & $252.5 \pm 1.8^{\mathrm{d}, \mathrm{B}}$ \\
\hline YO8 & $268.3 \pm 1.3^{\mathrm{c}, \mathrm{A}}$ & $272.9 \pm 2.0^{\mathrm{e}, \mathrm{B}}$ & $266.3 \pm 3.0^{\mathrm{e}, \mathrm{A}}$ & $265.9 \pm 3.2^{d, B}$ \\
\hline
\end{tabular}

Means within a row with different capital letters and means within a column with different small letters are differ significantly $(p<0.05)$. $\mathrm{C} 6=$ control, $60{ }^{\circ} \mathrm{C}$; KE6 = kefir, $60{ }^{\circ} \mathrm{C}$; $\mathrm{BM}=$ buttermilk, $60{ }^{\circ} \mathrm{C}$; YO6 = yogurt $60{ }^{\circ} \mathrm{C}$; $\mathrm{C} 6=$ control, $80^{\circ} \mathrm{C} ; \mathrm{KE} 6=$ kefir, $80^{\circ} \mathrm{C} ; \mathrm{BM}=$ buttermilk, $80^{\circ} \mathrm{C} ; \mathrm{YO} 6=$ yogurt $80^{\circ} \mathrm{C}$.

\subsection{Microbiological Analysis}

The advantage of SV products is their long shelf life without the need for the use of preservatives. Botinestean et al. [1] and Díaz et al. [2] found that vacuum conditions limit the growth of microorganisms and SV pasteurization ensures the proper microbiological quality of cooked meat. In our research, we did not store the SV-cooked steaks. After 3, 6, 9, and 12 days of marinating, the steaks were SV-cooked and cooled, and on the following day, the total counts of mesophilic and psychotropic aerobic bacteria were determined. All steaks contained acceptable threshold values for these microorganisms (less than $10 \log$ CFU g ${ }^{-1}$ or not at all), which proved successful SV pasteurization.

\section{Conclusions}

Marinating the meat in fermented dairy products (kefir, yogurt, and buttermilk) is a good alternative compared to other marinating methods. According to the literature, fermented milk products are natural products which are widely available, relatively cheap, and have a positive effect on human health. Marinating the meat in FDP increased the weight loss of SV-cooked steaks $\left(60\right.$ or $80{ }^{\circ} \mathrm{C}, 6 \mathrm{~h}$ ) compared to non-marinated steaks, but at the same time, it had no effect on the chemical composition and water activity. A few days of meat marinating, especially in buttermilk or yogurt, increased the safety of 
cooked steaks because it caused a significant slowdown in the fat oxidation reaction rate (reducing the TBARS value) and reduced the content of oxidizing substances (low RP value). In addition, the proposed process parameters (type of marinade, marinating time, temperature, and time of sous-vide cooking) effectively eliminated mesophilic and psychotropic oxygen bacteria. Further research should focus on the impact of the type of marinade (buttermilk and yogurt) and the time of meat marinating (within 6-9 days) on the optimization of sous-vide processing (mainly in $60^{\circ} \mathrm{C}$ ).

Author Contributions: Conceptualization, A.L. and J.L.; Methodology, A.L. and J.L.; Software, A.L. and J.L.; Validation, A.L. and J.L.; Formal Analysis, A.L. and J.L.; Investigation, A.L. and J.L.; Resources, A.L. and J.L.; Data A.L. and J.L.; Writing-Original Draft Preparation, A.L. and J.L.; Writing-Review \& Editing, A.L. and J.L.; Visualization, A.L. and J.L.; Supervision, A.L. and J.L.; Project Administration, A.L. and J.L.; Funding Acquisition, A.L. and J.L.

Funding: This research received no external funding.

Conflicts of Interest: The authors declare no conflict of interest.

\section{References}

1. Botinestean, C.; Keenan, D.F.; Kerry, J.P.; Hamilla, R.M. The effect of thermal treatments including sous-vide, blast freezing and their combinations on beef tenderness of $M$. semitendinosus steaks targeted at elderly consumers. LWT Food Sci. Technol. 2016, 74, 154-159. [CrossRef]

2. Díaz, P.; Nieto, G.; Garrido, M.D.; Bañón, S. Microbial, physical-chemical and sensory spoilage during the refrigerated storage of cooked pork loin processed by the sous vide method. Meat Sci. 2008, 80, $287-292$. [CrossRef] [PubMed]

3. Roldan, M.; Antequera, T.; Armenteros, M.; Ruiz, J. Effect of different temperature-time combinations on lipid and protein oxidation of sous-vide cooked lamb loins. Food Chem. 2014, 149, 129-136. [CrossRef] [PubMed]

4. Sanchez del Pulgar, J.; Gazquez, A.; Ruiz-Carrascal, J. Physico-chemical, textural and structural characteristic of sous-vide cooked pork cheeks as affected by vaccum, cooking temperature and cooking time. Meat Sci. 2012, 90, 828-835. [CrossRef]

5. Mozuriene, E.; Bartkiene, E.; Krungleviciute, V.; Zadeike, D.; Juodeikiene, G.; Damasius, J.; Baltusnikiene, A. Effect of natural marinade based on lactic acid bacteria on pork meat quality parameters and biogenic amine contents. LWT Food Sci. Technol. 2016, 69, 319-326. [CrossRef]

6. Yusop, S.M.; O'Sullivan, M.G.; Kerry, J.F.; Kerry, J.P. Effect of marinating time and low pH on marinade performance and sensory acceptability of poultry meat. Meat Sci. 2010, 85, 657-663. [CrossRef]

7. Żochowska-Kujawska, J.; Lachowicz, K.; Sobczak, M. Effects of fibre type and kefir, wine lemon, and pineapple marinades on texture and sensory properties of wild boar and deer longissimus muscle. Meat Sci. 2012, 92, 675-680. [CrossRef]

8. Pathania, A.; McKee, S.R.; Bilgili, S.F.; Singh, M. Antimicrobial activity of commercial marinades against multiple strains of Salmonella spp. Int. J. Food Microbiol. 2010, 139, 214-217. [CrossRef]

9. Xi, F.; Sebranek, J.G.; Lee, H.Y.; Ahn, D.U. Effects of adding red wine on the physicochemical properties and sensory characteristics of uncured frankfurter-type sausage. Meat Sci. 2016, 121, 285-291.

10. Jinap, S.; Hasnol, N.D.S.; Sanny, M.; Jahurul, M.H.A. Effect of organic acid ingredients in marinades containing different types of sugar on the formation of heterocyclic amines in grilled chicken. Food Control 2018, 84, 478-484. [CrossRef]

11. Kargiotou, C.; Katsanidis, E.; Rhoades, J.; Kontominas, M.; Koutsoumanis, K. Efficacies of soy sauce and wine base marinades for controlling spoilage of raw beef. Food Microbiol. 2011, 28, 158-163. [CrossRef] [PubMed]

12. FAO/WHO. Codex standard for fermented milks. Codex Stan 243-2003. 2011. Available online: http: //www.fao.org/3/i2085e/i2085e00.pdf (accessed on 12 October 2019).

13. Ben Fadhel, Y.; Leroy, V.; Dussault, D.; St-Yves, F.; Lauzon, M.; Salmieri, S.; Jamshidian, M.; Vu, D.K.; Lacroix, M. Combined effects of marinating and $\gamma$-irradiation in ensuring safety, protection of nutritional value and increase in shelf-life of ready-to-cook meat for immunocompromised patients. Meat Sci. 2016, 118, 43-51. [CrossRef] [PubMed] 
14. Fadda, S.; Lopez, C.; Vignolo, G. Role of lactic acid bacteria during meat conditioning and fermentation: Peptides generated as sensorial and hygienic biomarkers. Meat Sci. 2010, 86, 66-79. [CrossRef] [PubMed]

15. Olaoye, O.A.; Idowu, O. Features and functional properties of lactic acid bacteria used as biological preservatives of meat processing: A review article. J. Agric. Sci. Technol. 2010, 6, 449-460.

16. ISO. ISO 1442:1997: Meat and Meat Products-Determination of Moisture Content-Reference Method; ISO: Geneva, Switzerland, 1997.

17. ISO. ISO 1444:1996: Meat and Meat Products-Determination of Free Fat Content; ISO: Geneva, Switzerland, 1996.

18. ISO. ISO 2917:1999: Meat and Meat Products-Measurement of pH-Reference Method; ISO: Geneva, Switzerland, 1999.

19. Association of Official Analytical Chemists. 1AOAC Official Methods of Analysis; Association of Official Analytical Chemists: Washington, DC, USA, 2006.

20. Raharjo, S.; Sofos, J.N.; Schimidt, G.R. Improved speed, specificity, and limit of determination of an aqueous acid extraction thiobarbituric acid- C18 method for measuring lipid peroxidation in beef. J. Agric. Food Chem. 1992, 40, 2182-2185. [CrossRef]

21. ISO. ISO 6887-2:2017: Microbiology of the Food Chain-Preparation of Test Samples, Initial Suspension and Decimal Dilutions for Microbiological Examination-Part 2: Specific Rules for the Preparation of Meat and Meat Products; ISO: Geneva, Switzerland, 2017.

22. ISO. ISO 4833-1:2013: Microbiology of the Food Chain-Horizontal Method for the Enumeration of Microorganisms-Part 1: Colony Count at 30 Degrees C by the Pour Plate Technique; ISO: Geneva, Switzerland, 2013.

23. ISO. ISO 17410:2001: Microbiology of Food and Animal Feeding Stuffs-Horizontal Method for the Enumeration of Psychotropic Microorganisms; ISO: Geneva, Switzerland, 2001.

24. ISO. ISO 21528-2:2017: Microbiology of the Food Chain-Horizontal Method for the Detection and Enumeration of Enterobacteriaceae-Part 2: Colony-Count Technique; ISO: Geneva, Switzerland, 2017.

25. ISO. ISO 13720:2010: Meat and Meat Products-Enumeration of Presumptive Pseudomonas Spp; ISO: Geneva, Switzerland, 2010.

26. ISO. ISO 15214:1998: Microbiology of Food and Animal Feeding Stuffs-Horizontal Method for the Enumeration of Mesophilic Lactic Acid Bacteria-Colony-Count Technique at 30 Degrees C; ISO: Geneva, Switzerland, 1998.

27. Tornberg, E. Effects of heat on meat proteins-Implications on structure and quality of meat products. Meat Sci. 2005, 70, 493-508. [CrossRef]

28. Martens, H.; Staburvik, E.; Martens, M. Texture and colour changes in meat during cooking related to thermal denaturation of muscle proteins. J. Texture Stud. 1982, 13, 291-309. [CrossRef]

29. Gault, N.F.S. The relationship between water-holding capacity and cooked meat tenderness in some beef muscles as influenced by acidic conditions below the ultimate pH. Meat Sci. 1985, 15, 15-30. [CrossRef]

30. Medynski, A.; Pospiech, E.; Kniat, R. Effect of various concentrations of lactic acid and sodium chloride on selected physico-chemical meat traits. Meat Sci. 2000, 55, 285-290. [CrossRef]

31. Aktas, N.E.; Aksu, M.I.; Kaya, M. The effect of organic acid marination on tenderness cooking loss and bound water content of beef. J. Muscle Foods 2003, 14, 181-194. [CrossRef]

32. Bertram, H.C.; Kristensen, M.; Andersen, H.J. Functionality of myofibrillar proteins as affected by $\mathrm{pH}$, ionic strength and heat treatment-A low-field NMR study. Meat Sci. 2004, 68, 249-256. [CrossRef] [PubMed]

33. Zajsek, K.; Gorsek, A. Effect of natural starter culture activity on ethanol content in fermented dairy products. Int. J. Dairy Technol. 2010, 63, 113-118. [CrossRef]

34. Rodel, W.; Scheuer, R.; Wagner, H. A new method of determining water activity in meat products. Fleischwirtsch 1990, 70, 905-907.

35. Burke, R.M.; Monahan, F.J. The tenderisation of shin beef using a citrus juice marinade. Meat Sci. 2003, 63, 161-168. [CrossRef]

36. Koohmaraie, M. Muscle proteinases and meat ageing. Meat Sci. 1994, 16, 93-104. [CrossRef]

37. Pihlanto, A. Antioxidative peptides derived from milk proteins. Int. Dairy J. 2006, 16, 1306-1314. [CrossRef]

38. Diaz, M.; Decker, E.A. Antioxidant mechanisms of caseinophosphopeptides and casein hydrolysates and their application in ground beef. J. Agric. Food Chem. 2004, 52, 8208-8213. [CrossRef] [PubMed]

(C) 2019 by the authors. Licensee MDPI, Basel, Switzerland. This article is an open access article distributed under the terms and conditions of the Creative Commons Attribution (CC BY) license (http://creativecommons.org/licenses/by/4.0/). 